\title{
11. SURVEYS OF FOUR SITES IN THE TROPICAL WESTERN INDIAN OCEAN AS PREPARATION FOR DEEP SEA DRILLING PROJECT LEG 24
}

\author{
Phyllis B. Helms, Robert L. Fisher, Warren L. Smith, and Marie Z. Jantsch, Geological Research Division, \\ Scripps Institution of Oceanography, University of California at San Diego, La Jolla, California
}

\section{INTRODUCTION}

Geological-geophysical surveys of four proposed drilling sites (Figure 1) were conducted aboard R/V Melville (Scripps Institution of Oceanography) during a traverse from Port Louis, Mauritius to Mombasa, Kenya on ANTIPODE Expedition. Robert L. Fisher was chief scientist during this January-February 1971 period.

The surveys were carried out with airgun (reflection profiling), magnetometer, $3.5 \mathrm{kHz}$ and supplementary $12-\mathrm{kHz}$ echo sounders, and deep-sea stereo camera. Gravity observations were not made on ANTIPODE Expedition. All four sites had been planned for drilling on Glomar Challenger's Leg 23, but they were subsequently rescheduled for Leg 24 . Numbering adopted here is consistent with the Leg 24 prospectus of 2 March 1972.

Funding for these surveys was obtained from the National Science Foundation, principally via Grants GL-26475 (NOSCP) and GA-23335 (DES). The Office of Naval Research provided additional support for ANTIPODE Expedition. Miss Frances L. Parker and Peter H. Roth assisted in identification of foraminifers and nannofossils, respectively. Judy Clinton helped prepare the illustrations.

\section{ANTIPODE SITE SURVEY 24-7 (EASTERN PART OF SOMALI BASIN)}

\section{Location and Background}

The area examined on the Site $24-7^{1}$ survey is bounded by latitudes $1^{\circ} 15^{\prime} \mathrm{S}$ and $2^{\circ} 00^{\prime} \mathrm{S}$ and by longitudes $57^{\circ} 10^{\prime} \mathrm{E}$ and $58^{\circ} 05^{\prime} \mathrm{E}$. The point ultimately recommended for drilling lies at $1^{\circ} 39.0^{\prime} \mathrm{S}, 57^{\circ} 37.0^{\prime} \mathrm{E}$ (between $\mathrm{D}$ and $\mathrm{E}$, Figures 2 and 3), in a water depth of 4483 meters (corrected).

The deep-water locality was chosen for its position near the southernmost identifiable prominent anomaly north of the Seychelles Islands block (Fisher et al., 1968) and for the presence of a stratified, low-latitude pelagic sediment sequence which overlies a regionally smooth basement. Drilling here should contribute important evidence as to when the Seychelles block broke away from India and permit a check on the magnetic time scale through dating of basal sediment-basement(?) contact by fossils.

\section{Topographic, Structure, and Site Survey Data}

Melville's detailed survey indicates that the deepest recognizable reflector lies at 0.35 to $0.38 \mathrm{sec}$ (two-way). This horizon is not a strong reflector and may not mark

\footnotetext{
${ }^{1}$ Drilled as Hole 236.
}

igneous basement. However, what appears to be a volcanic surface approaches and at some points breaks through the relatively flat sediment-water boundary (Figure 3 ). The overall topographic trend is northwesterly (Figure 2), more or less paralleling Carlsberg Ridge.

Sample locations are all slightly southwest of their intended positions due to very strong west-southwesterly drift that made sampling difficult. Furthermore, because of this drift and the electrical interference that obliterated pinger signals whenever Melville's aft cycloid was activated to hold location, the camera could not be controlled closely enough to secure usable photographs of the flat bottom.

Heat flow was measured as $1.4 \mu \mathrm{cal} / \mathrm{cm}^{2} / \mathrm{sec}$, a preliminary value. Location of the probe site, as ANTP $152 \mathrm{HF}$, was $1^{\circ} 43.2^{\prime} \mathrm{S}, 57^{\circ} 31.3^{\prime} \mathrm{E}$, in a water depth of 4448 meters (corrected). Magnetic profiles display little relief, but reflect topography.

A 516-cm piston core (ANTP 150P) was obtained at $1^{\circ} 39.6^{\prime} \mathrm{S}, 57^{\circ} 35.3^{\prime} \mathrm{E}$, in a water depth of 4482 meters (corrected). This core consisted of calcareous ooze (both foraminiferal and nannofossil), with some siliceous microfossils, primarly radiolarians. Age of this material is Quaternary, but includes many admixed or reworked Pliocene microfossils.

\section{ANTIPODE SITE SURVEY 24-8 (MASCARENE PLATEAU, ON THE SADDLE BETWEEN THE SEYCHELLES ARCHIPELAGO AND SAYA DE MALHA BANK)}

\section{Location and Background}

The area surveyed to select and provide context for Site $24-8^{2}$ is bounded by latitudes $6^{\circ} 40^{\prime} \mathrm{S}$ and $7^{\circ} 30^{\prime} \mathrm{S}$ and by longitudes $57^{\circ} 35^{\prime} \mathrm{E}$ and $58^{\circ} 25^{\prime} \mathrm{E}$. The locality recommended for drilling by Glomar Challenger lies at $7^{\circ} 04.3^{\prime} \mathrm{S}$, $58^{\circ} 08.2^{\prime} \mathrm{E}$ (between C-D-U, Figure 4), in a water depth of 1620 meters (corrected), on a ridge of the first extensive reflector that may be basement.

Both Sites $24-8$ and $24-9$ were proposed in order to determine how much of the Mascarene Plateau and its borders are underlain by continental-type granitic rocks. Near Site 24-8, reflection results (Bunce et al., 1966) indicate the drill would penetrate calcareous sediments, perhaps subsided reef material, and basement material. The nature of the material underlying the northwest-trending link between apparently volcanic Saya de Malha (Shor and Pollard, 1963) and the granitic Seychelles Islands block remains a point of controversy. Some have suggested that

\footnotetext{
${ }^{2}$ Drilled as Hole 237.
} 


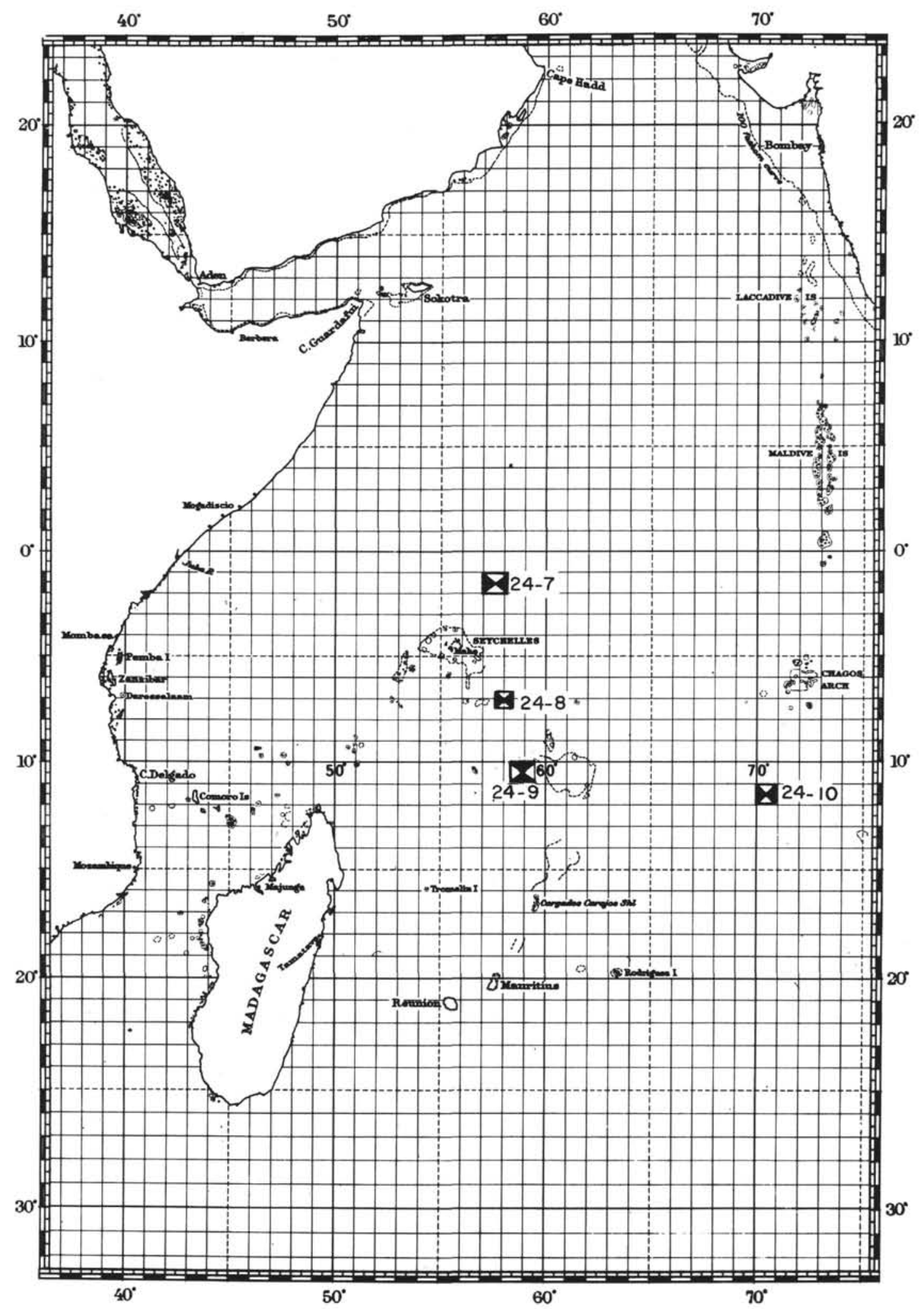

Figure 1. Four potential sites surveyed by $R / V$ Melville (SIO) in January-February, 1971, on ANTIPODE Expedition. Only Site Survey 24-9 was not drilled on Leg 24. 


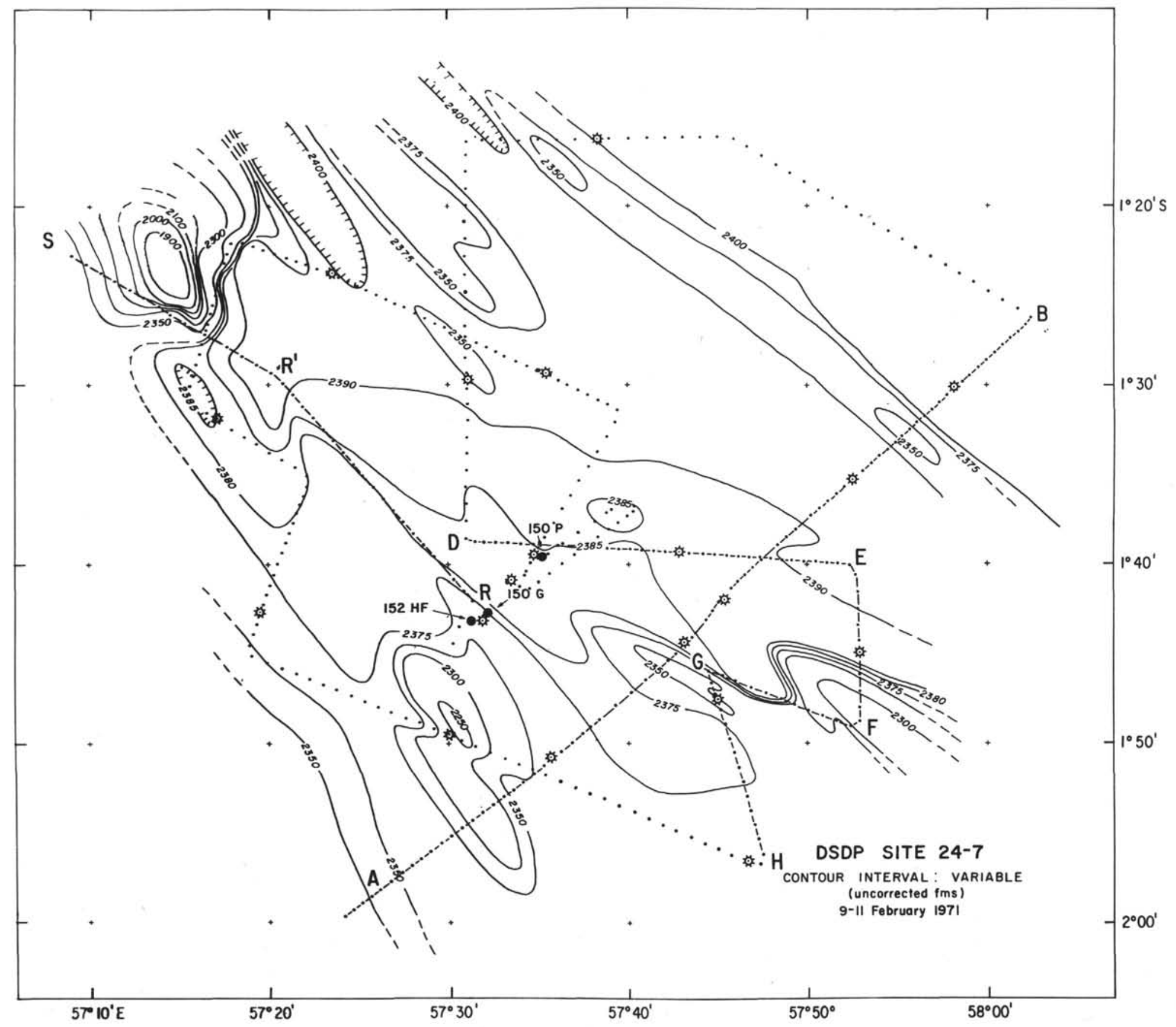

Figure 2. Topography and sampling localities based on Melville's exploration, February 1971. Dots represent sounding points; spiked circles represent satellite fixes. Letters connected by dashed lines are turning points indicated on the seismic reflection profiles, Figure 3. 


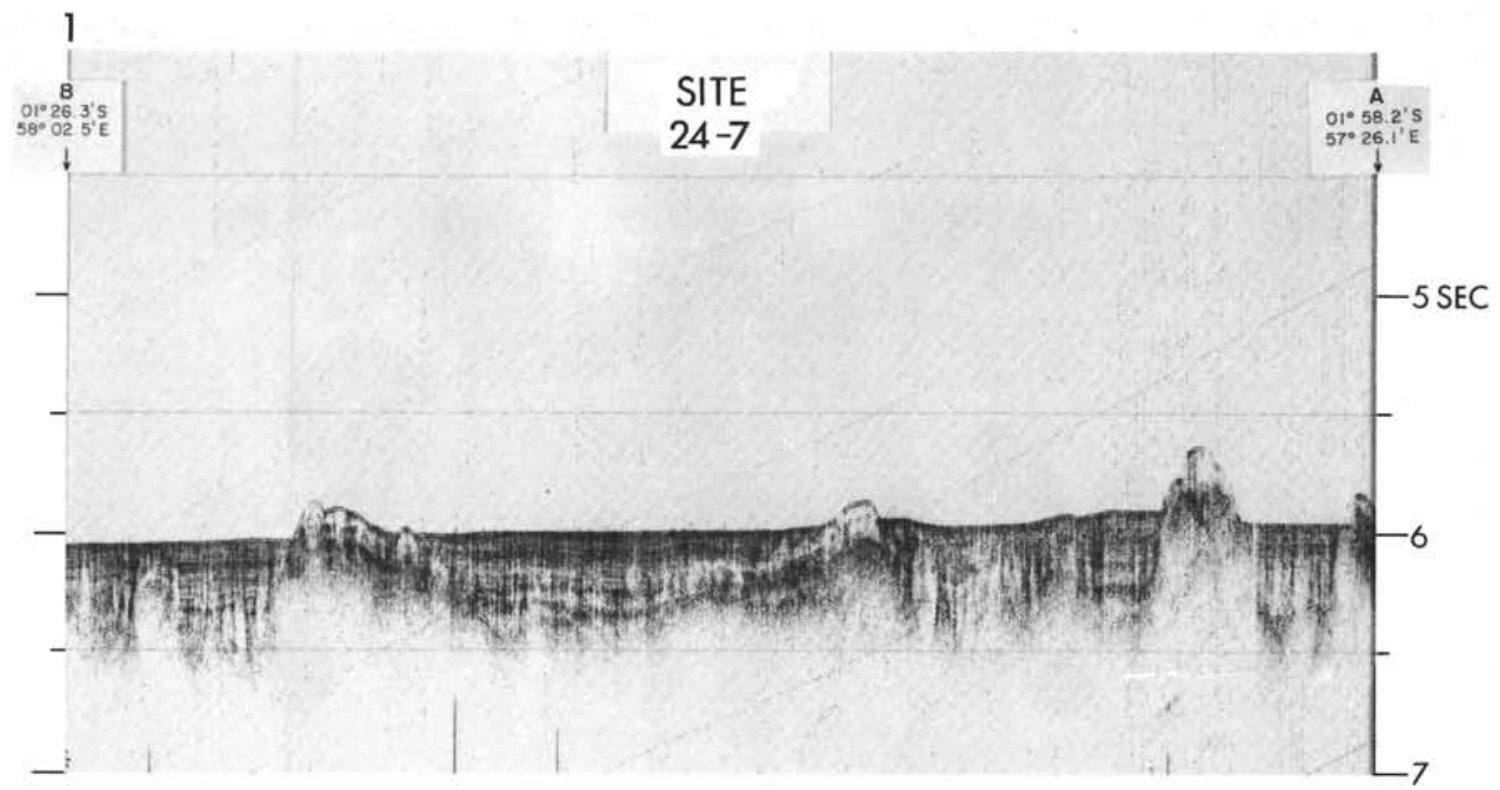

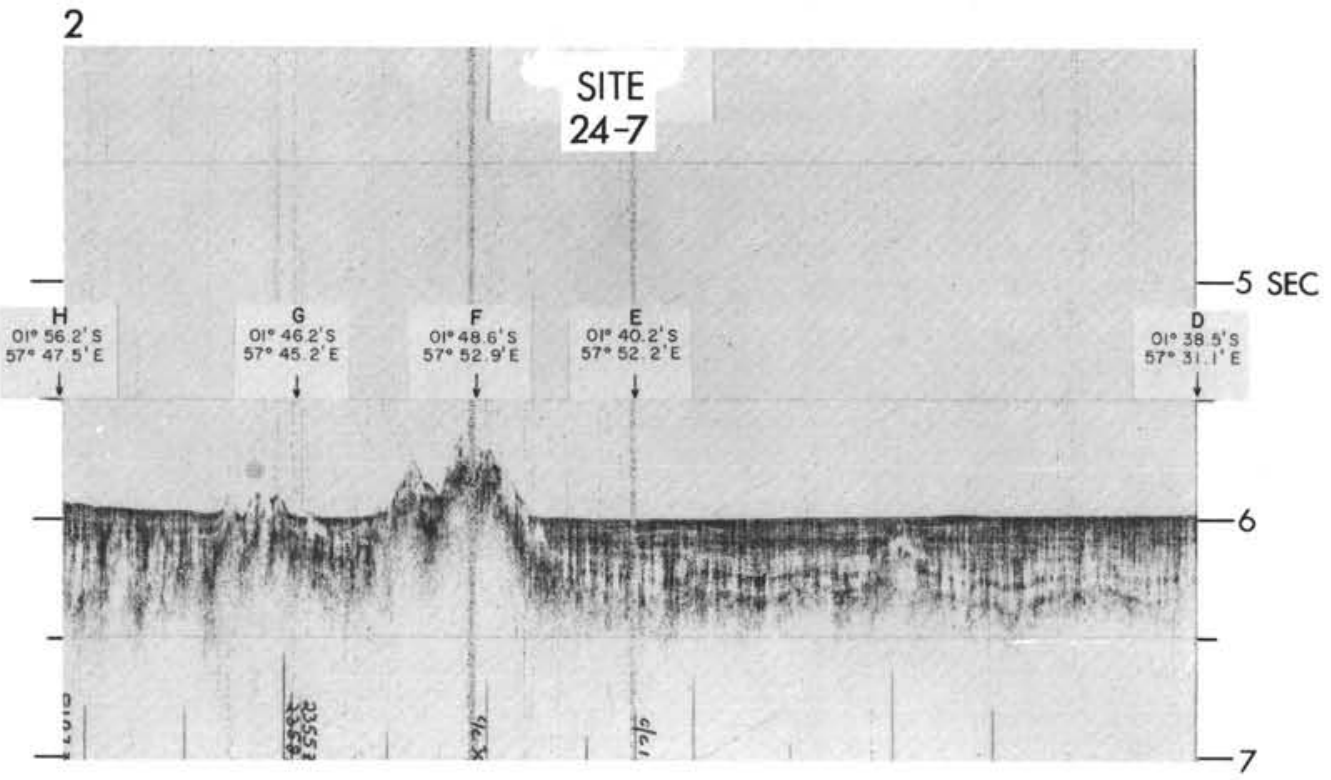

Figure 3. Selected airgun profiles, Site Survey 24-7.

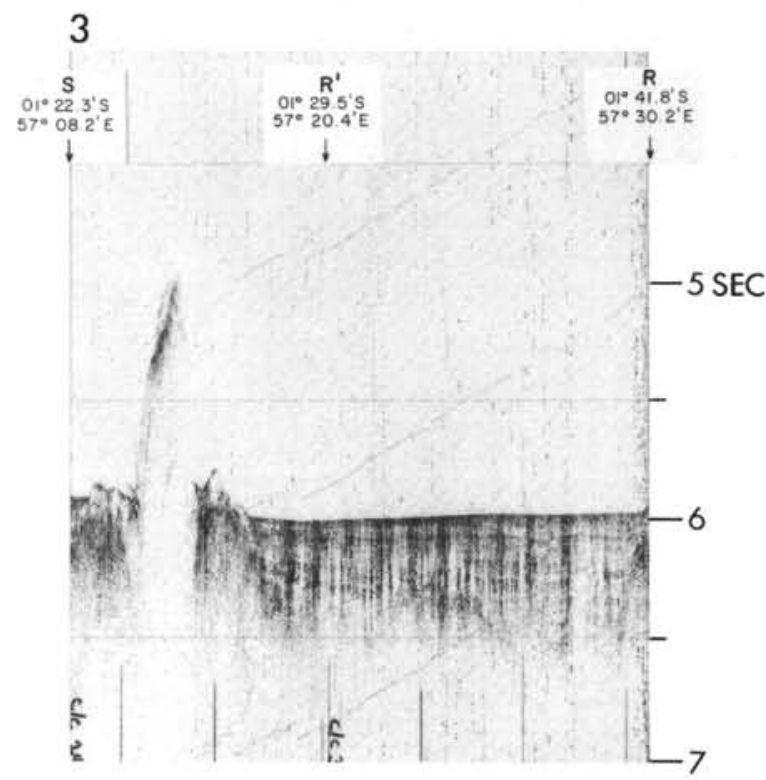

NOTE: See Figure 2 for location of profiles. 
volcanism built Saya de Malha's foundation, and that this activity has migrated southward perhaps since Miocene time (Fisher et al., 1971). A time scale for subsidence is required; however, since the calcareous section may be hard indurated sediments and the hole ideally must bottom in igneous rock of one type or another, the most favorable locale would have a thin but complete sedimentary section overlying a shoal basement. Melville's survey was directed toward finding such a locality.

\section{Topography, Structure, and Site Survey Data}

The western side of the ridge is steep (Figure 4), trending northwest with a volcanic(?) rampart adjacent to the fault scarp. This rampart has high magnetic relief as well, as shown by Bunce et al. (1966, p. 222, profile 2), and by Melville's profiles. However, a dredge haul at $7^{\circ} 20.0^{\prime} \mathrm{S}$, $57^{\circ} 56.3^{\prime} \mathrm{E}$ (near point T, Figure 6 IV), at a depth of 2430-2265 meters on the scarp yielded-after extremely high wire tensions-only cavernous and porous reef limestones coated with a thick crust of manganese oxides. This suggests that the ancient reef area and its foundation may have been much more extensive, have been jostled and slivered by faulting, and intruded by large dikes. Then, with subsidence, such dikes or peaks(?) were lapped by calcareous sediments and debris showing faint layering on the airgun records (Figure 6 III, IV). A few kilometers northeast of the scarp magnetic relief is low, and the basement, whether volcanic or granitic, may be more uniform. Both the gross topographic chart (Figure 4) and the preliminary isopach map on the first strong, extensive reflector (Figure 5) bear out the northwest structural grain.

Bottom photographs taken on camera station ANTP $148 \mathrm{C}$ show a strongly ripple-marked bottom, with organic debris on the ripple crests, and a few tracks of benthic animals (Figure 7). Such current ripples are common on isolated elevations even at considerable depths.

Air gun records are good and reveal that a particularly strong reflector, with moderate relief on its surface and evidence of faulting, is present throughout the region surveyed at "depths" of 0.2 to $0.85 \mathrm{sec}$, two-way (Figure 6). Locally, a fairly discrete reflector lies just above this zone (see A-B' or near X, Figures 4,6 ), and sometimes faint reflectors that do not appear to be multiples (because of lensing) occur below it. This is particularly true in the C-D-U area suggested for drilling. A northwest-trending graben shows at $\mathrm{M}, \mathrm{W}$, between $\mathrm{O}$ and $\mathrm{P}$, and between $\mathrm{X}$ and $\mathrm{X}^{\prime}$. Drilling in that down-dropped feature might provide a more complete basal section. Above the strong intermediate reflector, layering is less continuous and also is contorted, compacted, and subdued.

Melville's magnetic anomaly plots in the surveyed area are irregular to the west, with very small period, and more subdued in the eastern section, bearing out the Chain 45 magnetic profile 2 (Bunce et al., 1966). Heat-flow stations ANTP 147A and 147B were unsuccessful; on both attempts insufficient penetration was achieved.

A piston core, ANTP $146 \mathrm{P}$, was obtained ar $7^{\circ} 02.4^{\prime} \mathrm{S}$, $58^{\circ} 09.9^{\prime} \mathrm{E}$, in a water depth of 1638 meters (corrected). The core, $311 \mathrm{~cm}$ in length, consists of Quaternary foraminiferal-nannoplankton ooze with no siliceous microfossils.

\section{ANTIPODE SITE SURVEY 249 \\ (LOWER FLANK OF THE MASCARENE PLATEAU WEST OF SAYA DE MALHA BANK)}

\section{Location and Background}

The area surveyed in order to select drilling Site $24-9^{3}$ is bounded by latitudes $10^{\circ} 05^{\prime} \mathrm{S}$ and $10^{\circ} 50^{\prime} \mathrm{S}$ and longitudes $58^{\circ} 30^{\prime} \mathrm{E}$ and $59^{\circ} 30^{\prime} \mathrm{E}$. The point ultimately recommended for drilling lies at $10^{\circ} 18.0^{\prime} \mathrm{S}, 58^{\circ} 56.0^{\prime} \mathrm{E}$, in a water depth of 2826 meters (corrected).

This site originally was suggested for drilling because of the presence of a layer of 5.5 to $6.0 \mathrm{~km} / \mathrm{sec}$ compressional wave velocity overlain by a thin layer of low-velocity sediments. Drilling here would provide an opportunity to sample the high velocity material occurring at shallow depth to determine whether it is granitic, like the Seychelles block $500 \mathrm{~km}$ to the northwest, or volcanic like oceanic basement. Seismic refraction data from LUSIAD Expedition published by Francis and Shor (1966) shows, between their stations 25 (approximately $10^{\circ} 21^{\prime} \mathrm{S}$, $58^{\circ} 30^{\prime} \mathrm{E}$, depth $3460 \mathrm{~m}$ ) and 26 (approximately $10^{\circ} 29^{\prime} \mathrm{S}$, $59^{\circ} 23^{\prime} \mathrm{E}$, depth $2840 \mathrm{~m}$ ), a crustal section of 0.3 to $0.4 \mathrm{~km}$ of $2.15 \mathrm{~km} / \mathrm{sec}$ (assumed velocity) sediment, 2.4 to $3.2 \mathrm{~km}$ of $5.5 \mathrm{~km} / \mathrm{sec}$ material, and 9 to $12 \mathrm{~km}$ of $6.03 \mathrm{~km} / \mathrm{sec}$ material. Following the weighted preferences as expressed by Francis and Shor, four possible composition combinations of the deeper two layers (5.5 and $6.03 \mathrm{~km} / \mathrm{sec}$, respectively) would be volcanics-granitics(?), graniticsgranitics(?), hard limestone-granitics(?), or basalt-basalt(?). This site should be drilled only if granitic or similarly "non-oceanic" basement rock is not obtained at Site 24-8.

\section{Topography, Structure, and Site Survey Data}

Bathymetric exploration portrays the region as a gullied or dissected slope, with a more regular sedimented toe or apron in the southern sector. Disruption is abrupt in the westerly direction, but dissection is limited to the area northeast of a line connecting B and D (Figure 8).

Melville's airgun records on this survey are clear, and one profile (D-E, not reproduced in Figure 9) lies very close to the Francis-Shor LUSIAD 25-26 refraction line. It shows the deepest reflector to be obvious and continuous at "depths" of 0.2 to $0.4 \mathrm{sec}$ (two-way), thus correlating well with the top of their $5.5 \mathrm{~km} / \mathrm{sec}$ material. North of $10^{\circ} 30^{\prime} \mathrm{S}$ the topography of the sea floor becomes more rugged from faulting, slumping, or gulleying on the slope, and a widespread intermediate reflector within the sediments appears 0.15 to $0.2 \mathrm{sec}$ above the deepest reflector; this shoaler reflector seems to outcrop at $\mathrm{S}^{\prime}$ and $\mathrm{T}$ (Figure 9I). At the point recommended for drilling, between $F$ and $G$ (Figure 9 IV), the reflection profile shows about $0.2 \mathrm{sec}$ to the intermediate reflector and $0.4 \mathrm{sec}$ to the deepest horizon.

A piston core $181 \mathrm{~cm}$ in length, ANTP 142P, was obtained at $10^{\circ} 16.9^{\prime} \mathrm{S}, 58^{\circ} 58.1^{\prime} \mathrm{E}$ in a water depth of 2763 meters (corrected). The cored sediments consisted of foraminiferal ooze of Quaternary age and contained a relatively small amount of siliceous microfossils, primarily radiolarians.

\footnotetext{
${ }^{3}$ Not drilled.
} 


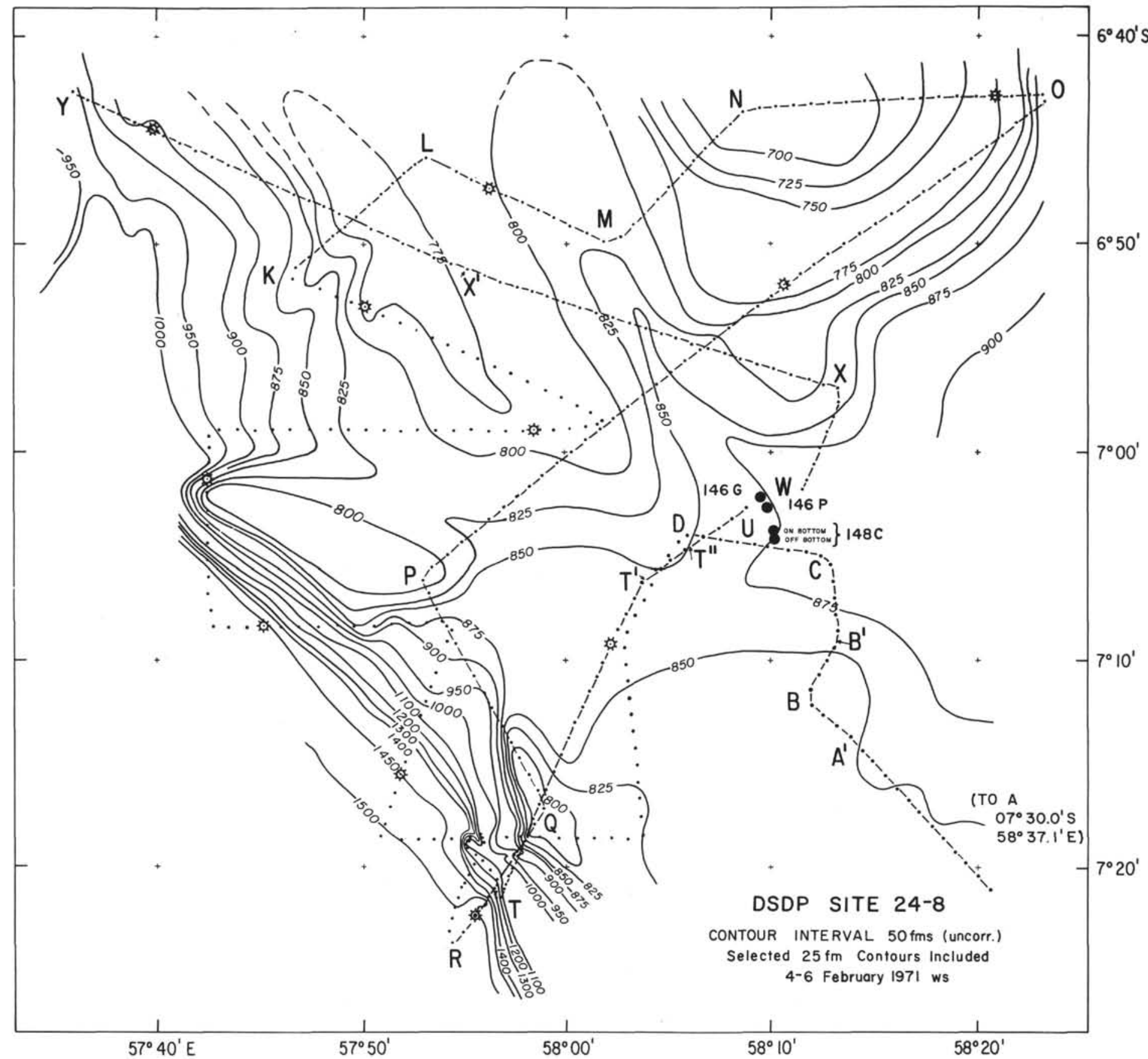

Figure 4. Topography and sampling localities, from Melville's exploration, February 1971. Symbols as for Figure 2. 


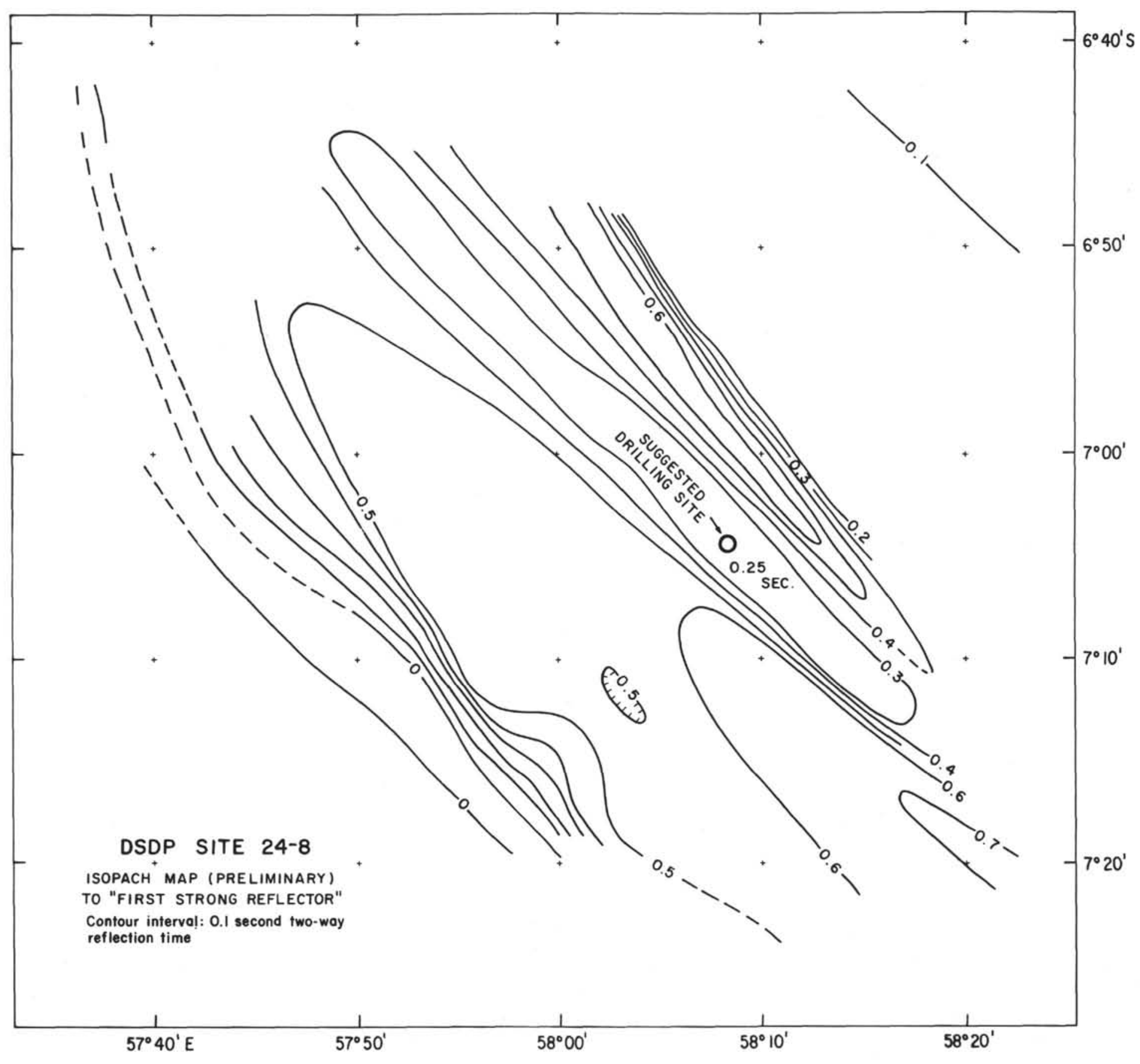

Figure 5. Preliminary "isopach" map, Site Survey 24-8. 
P. B. HELMS, R. L. FISHER, W. L. SMITH, M. Z. JANTSCH
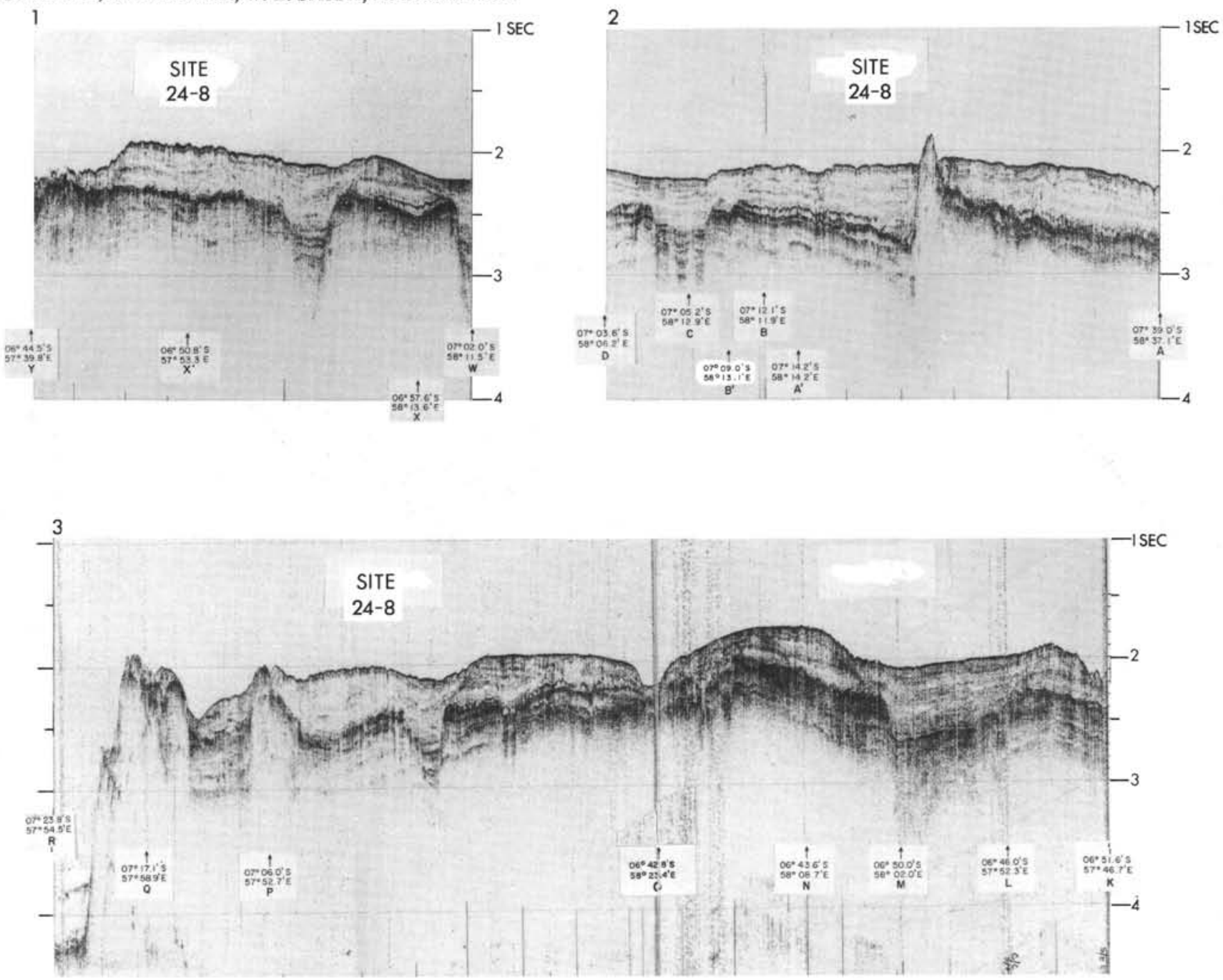

NOTE: The "shadow" is a dangling weighted rod to indicate the vertical.

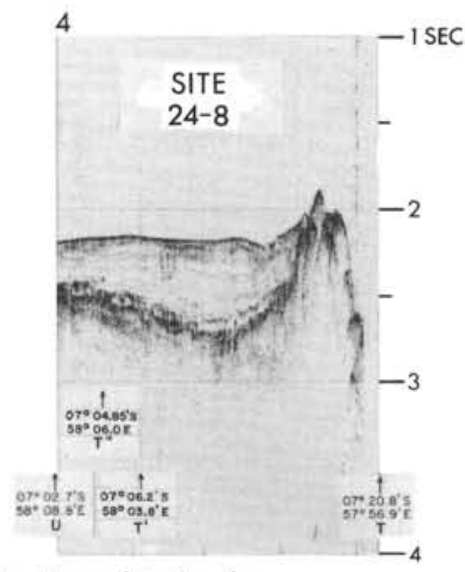

NOTE: See Figure 4 for location of reflection profiles.

Figure 6. Selected airgun profiles, Site Survey 24-8.

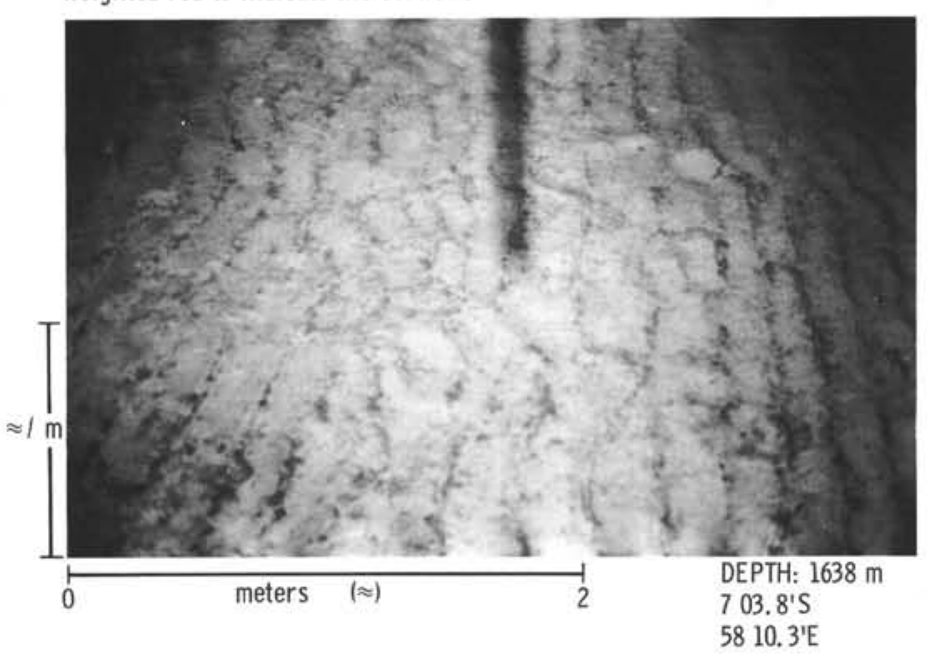

Figure 7. Photograph of typical bottom at ANTP $148 \mathrm{C}$. (Camera: E. G. and G. 200 A). 


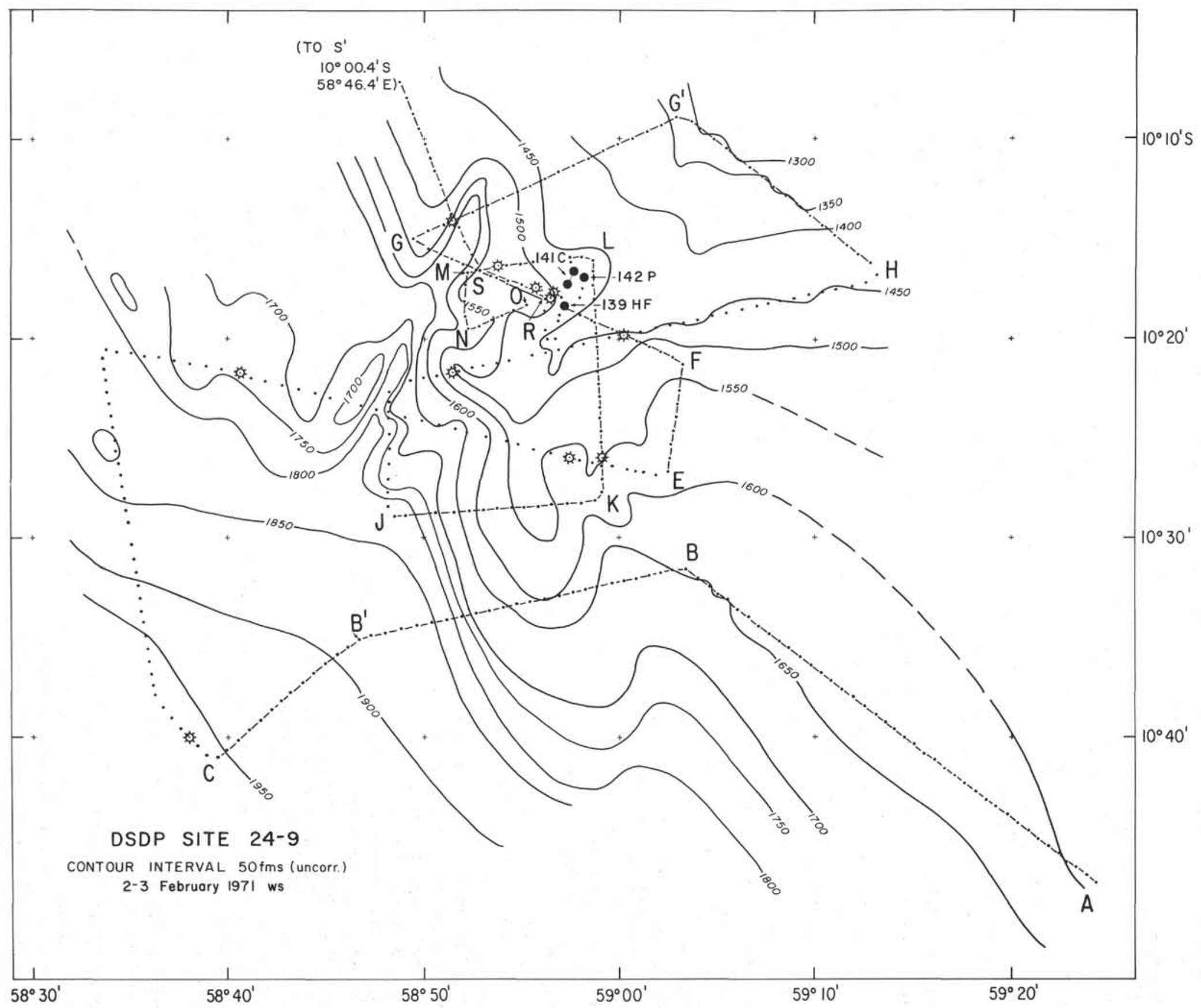

Figure 8. Topography and sampling localities, from Melville's exploration, February 1971. Symbols as for Figure 2. 
Photographs from camera station ANTP $141 \mathrm{C}$ $\left(10^{\circ} 17.7^{\prime} \mathrm{S}, 58^{\circ} 56.6^{\prime} \mathrm{E}\right.$, at $\left.2790 \mathrm{~m}\right)$ reveal a rather mottled smooth sedimented bottom, with occasional tracks and some animal life (Figure 10). The photograph chosen shows one small fish, the only vertebrate observed.

Heat flow was measured as ANTP $139 \mathrm{HF}$ at $10^{\circ} 18.2^{\prime} \mathrm{S}$, $58^{\circ} 57.0^{\prime} \mathrm{E}$, in a water depth of 2784 meters (corrected). A preliminary value of $1.1 \mu \mathrm{cal} / \mathrm{cm}^{2} / \mathrm{sec}$ was obtained. Melville's magnetic profiles from this survey were not striking, but they have not been examined in detail.

\section{ANTIPODE SITE SURVEY 24-10 \\ (INTERSECTION OF ARGO FRACTURE ZONE WITH THE SOUTHERN PART OF THE CHAGOS-LACCADIVE RIDGE)}

\section{Location and Background}

The region examined to select and provide context for Site $24-10^{4}$ is bounded by latitudes $11^{\circ} 00^{\prime} \mathrm{S}$ and $11^{\circ} 50^{\prime} \mathrm{S}$ and longitudes $70^{\circ} 00^{\prime} \mathrm{E}$ and $70^{\circ} 55^{\prime} \mathrm{E}$. The locale proposed for drilling by Glomar Challenger lies at $11^{\circ} 08.5^{\prime} \mathrm{S}$, $70^{\circ} 30.5^{\prime} \mathrm{E}$, in a depth of 2825 meters (corrected).

Drilling at Site 24-10 was proposed in order to obtain a good pelagic sequence and, if possible, to determine the nature and age of the basement rock of the ChagosLaccadive Ridge. It has been postulated by some authors (Francis and Shor, 1966, for example) that the volcanism building that ridge has moved north with time. If this is so, the oldest sediments and the most complete section should occur near $11^{\circ}-12^{\circ} \mathrm{S}$. Francis and Shor relate this volcanism to the early Tertiary Deccan Traps of western India.

Regional studies carried out on ANTIPODE Expedition in 1971 reveal that the site proposed lies near the intersection of the Chagos-Laccadive Ridge and the northeast end of the Argo Fracture Zone. This zone-or swarm-is one of the transform fault systems that, according to Fisher et al. (1971), has developed with northeast-southwest spreading of the Central Indian Ridge since perhaps mid-Miocene time. This behavior has permitted the separation of Chagos. Archipelago from the vicinity of the neck between Saya de Malha and Nazareth Bank. Crossings normal to the transform fault systems' trend and successively farther from the active mid-ocean ridge crest do show increasingly thick sediments within the cross-fracture. Drilling entirely through the sediments and into the basement within a recognizable buried crossfracture in the surveyed area could establish or confirm the approximate date of the initial separation of two major topographic members of the Indian Ocean: the middle (volcanic) portion of the Mascarene Plateau and the south end of the Chagos-Laccadive Ridge. Drilling should continue sufficiently far into the basement to obtain fresh massive flow material.

\section{Topography, Structure, and Site Survey Data}

The topographic chart (Figure 11) vis-à-vis buried structure is the less clearly lineated in a northeast-southwest direction due to blanketing by sediments, but that grain can be seen in the basement ridge-trough system (isopach map, Figure 12).

\footnotetext{
${ }^{4}$ Drilled as Hole 238.
}

Melville's airgun records in the area are good and easy to interpret. They reveal a simple picture of stratified sediments over well-defined basement. The reflector taken to represent basement approaches the sea floor, particularly in the northern sector, but there also sediment reaches its maximum thickness constrained by basement ridges within the fracture zone (Figure 13; C, G, J, L, V). South of $11^{\circ} 25^{\prime} \mathrm{S}$, basement relief is small and the sediment, not markedly stratified, reaches a thickness of 0.25 to $0.45 \mathrm{sec}$, two-way (Figure 13, near F or W). Argo's 1968 CIRCE line, which led to the proposing of this site, crossed this area.

A northeast- or east-trending trough is centered near $\mathrm{G}^{\prime}-\mathrm{O}-\mathrm{L}$ (Figure 13) at about $11^{\circ} 10^{\prime} \mathrm{S}, 70^{\circ} 31^{\prime} \mathrm{E}$. It displays maximum sediment thickness of $0.55 \mathrm{sec}$ between $\mathrm{C}$ and $\mathrm{D}$ and between $\mathrm{G}^{\prime}$ and $\mathrm{H} ; 0.50$ to 0.55 between $\mathrm{K}, \mathrm{L}$, and $\mathrm{M}$; and $0.55 \mathrm{sec}$ near 0 , where the airgun was retrieved and sampling begun. The basal 0.15 to $0.2 \mathrm{sec}$ of the column, possibly turbidites, displays more obvious and more contorted layering. Farther west, along traverse V-W, this trough is less well developed, lying slightly over halfway from V to W. Similar but less thickly sedimented and less well defined troughs lie between $F$ and $G$ in the south-central portion of the area explored and near $V$ in the northwest sector, where yet another member of the "Argo Fracture Zone swarm," and perched sediment lip, occurs. A less thickly sedimented and possibly recently active cleft trends northeast through I (Figures 11, 12, 13II).

Piston core ANTP 120P, $270 \mathrm{~cm}$ in length, was obtained at $11^{\circ} 08.4^{\prime} \mathrm{S}, 7^{\circ} 31.4^{\prime} \mathrm{E}$, in 2825 meters (corrected) of water. It consisted of calcareous ooze and no siliceous microfossils. The foraminifera were of admixed middle Miocene to Quaternary age, and the nannofossils at the bottom of the core were of lower Pliocene age.

Camera station ANTP $121 \mathrm{C}\left(11^{\circ} 08.4^{\prime} \mathrm{S}, 70^{\circ} 30.2^{\prime} \mathrm{E}\right.$, water depth $2818 \mathrm{~m}$ ) yielded photographs showing a mottled, pock-marked, tracked, apparently firm bottom surface with holothurians, sea fans, and anemonoid-like creatures (Figure 14).

A preliminary heat-flow value of $-0.17 \mu \mathrm{cal} / \mathrm{cm}^{2} / \mathrm{sec}$ was obtained as ANTP $122 \mathrm{HF}$ at $11^{\circ} 08.5^{\prime} \mathrm{S}, 70^{\circ} 30.7^{\prime} \mathrm{E}$, in a water depth of 2825 meters (corrected). No rigorous explanation of this negative reading is easily at hand. Melville's magnetic anomaly profiles show considerable relief, but their relation to the obvious basement topography has not been determined.

\section{REFERENCES}

Bunce, E. T., Bowin, C. O., and Chase, R. L., 1966. Preliminary results of the 1964 cruise of R/V Chain to the Indian Ocean: Phil. Trans. Roy. Soc. London, Series A, v. 259 , p. $218-226$.

Fisher, R. L., Engel, G. G., and Hilde, T. W. C., 1968. Basalts dredged from the Amirante Ridge, western Indian Ocean: Deep-Sea Res., v. 15, p. 521-534.

Fisher, R. L., Sclater, J. G., and McKenzie, D. P., 1971. Evolution of the Central Indian Ridge, western Indian Ocean: Geol. Soc. Am. Bull., v. 82, p. 553-562.

Francis, T. J. G. and Shor, G. G., Jr., 1966. Refraction measurements in the northwest Indian Ocean: J. Geophys. Res., v. 71, p. 427-449.

Shor, G. G., Jr. and Pollard, D. D., 1963. Seismic investigations of Seychelles and Saya de Malha banks, northwest Indian Ocean: Science, v. 142, p. 48-49. 

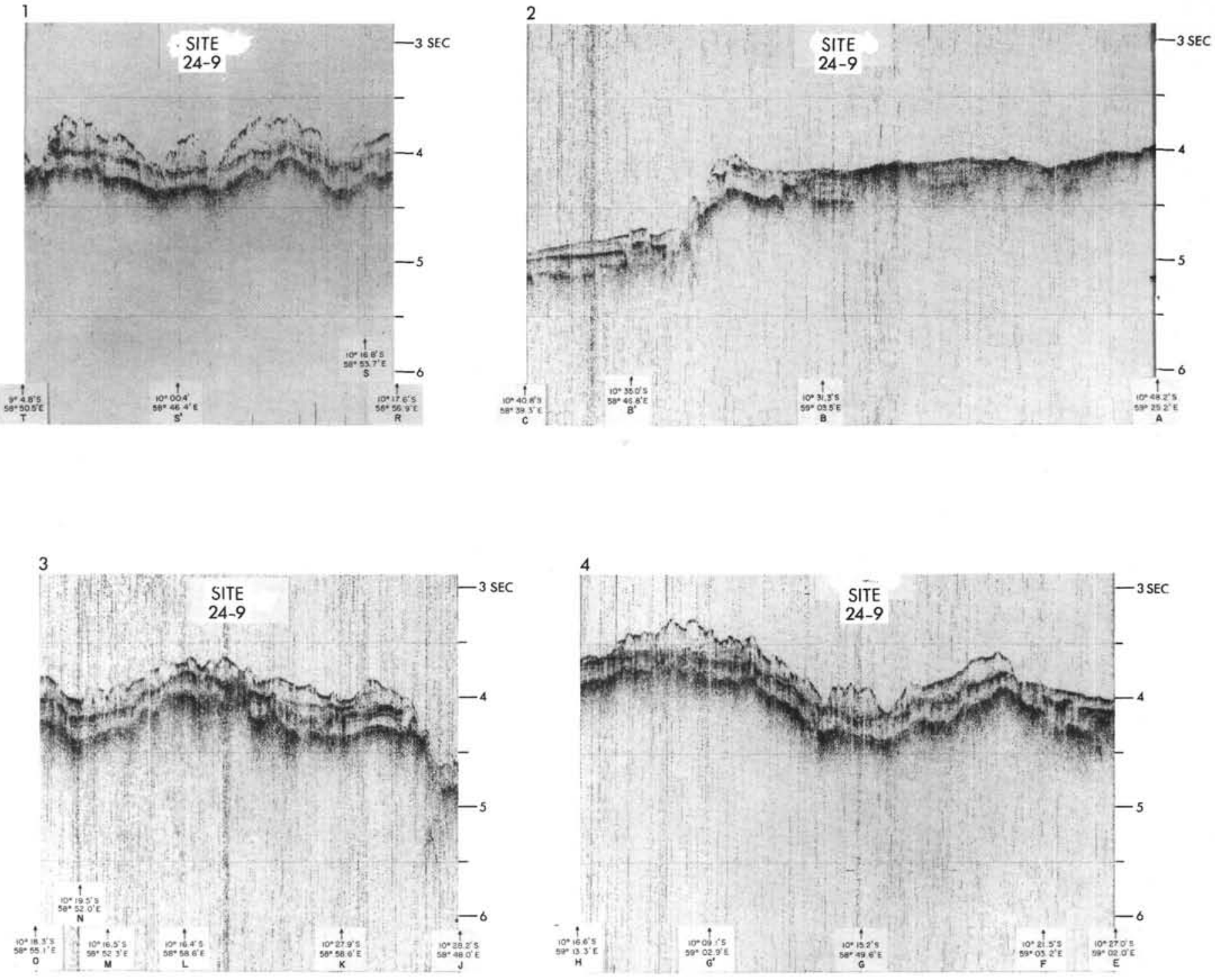

NOTE: See Figure 8 for location of reflection profiles.

Figure 9. Selected airgun profiles, Site Survey 24-9.

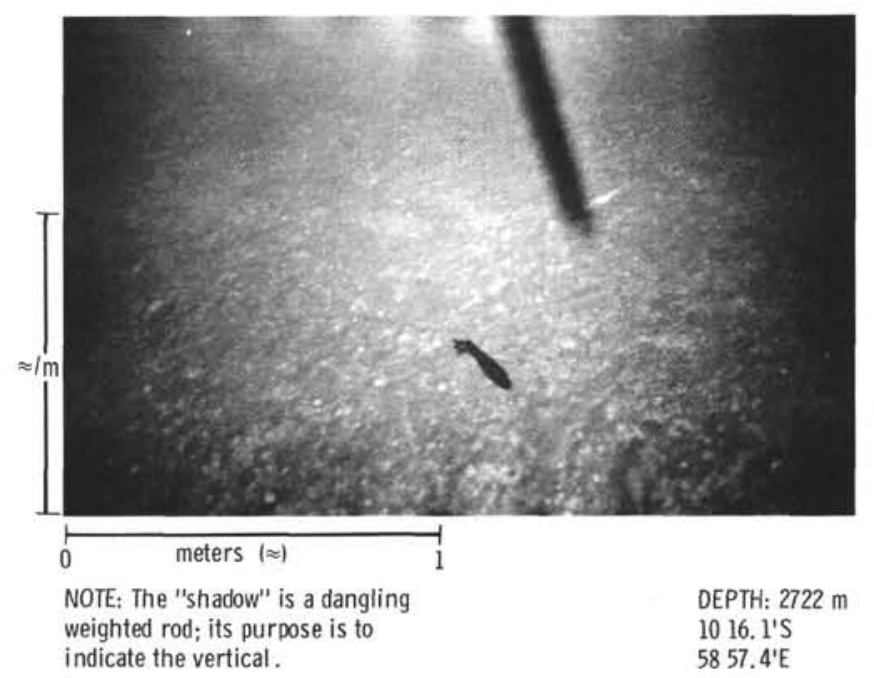

Figure 10. Typical bottom photographed at ANTP 141C. The fish seems about $20-25 \mathrm{~cm}$ long. 


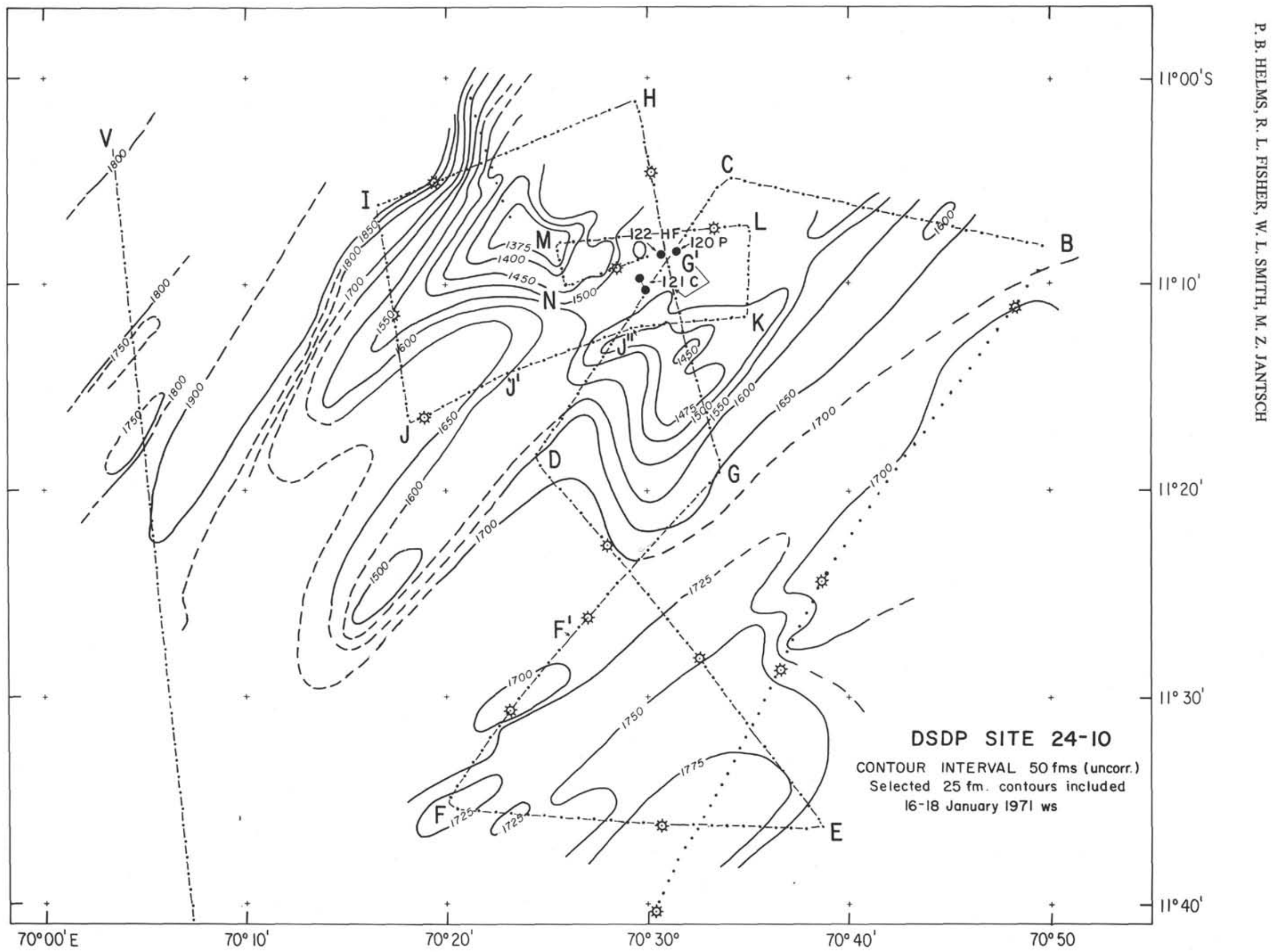

Figure 11. Topography and sampling localities, from Melville's exploration, January 1971. Symbols as for Figure 2. 


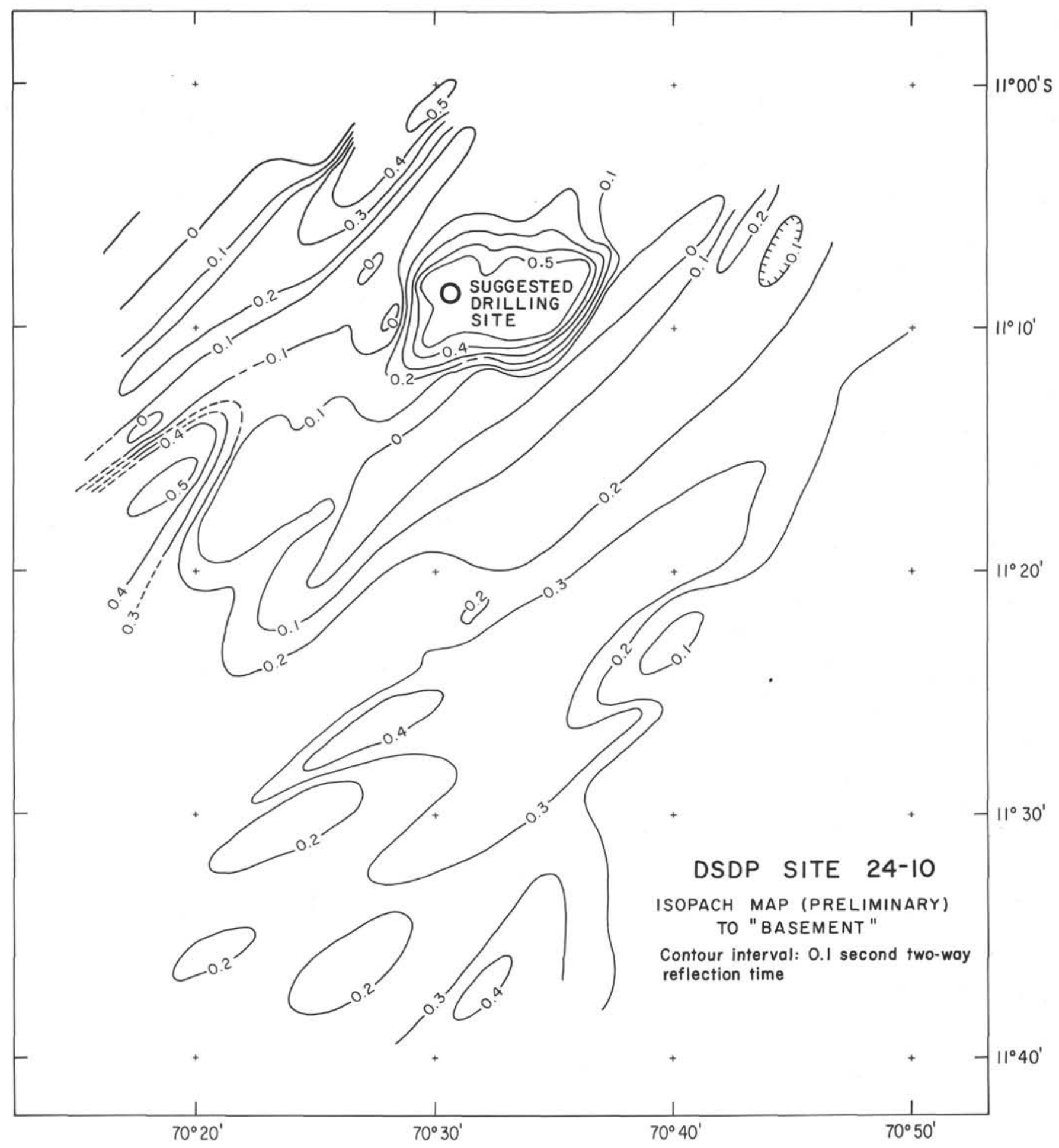

Figure 12. Preliminary "isopach" map, Site Survey 24-10. 
P. B. HELMS, R. L. FISHER, W. L. SMITH, M. Z. JANTSCH
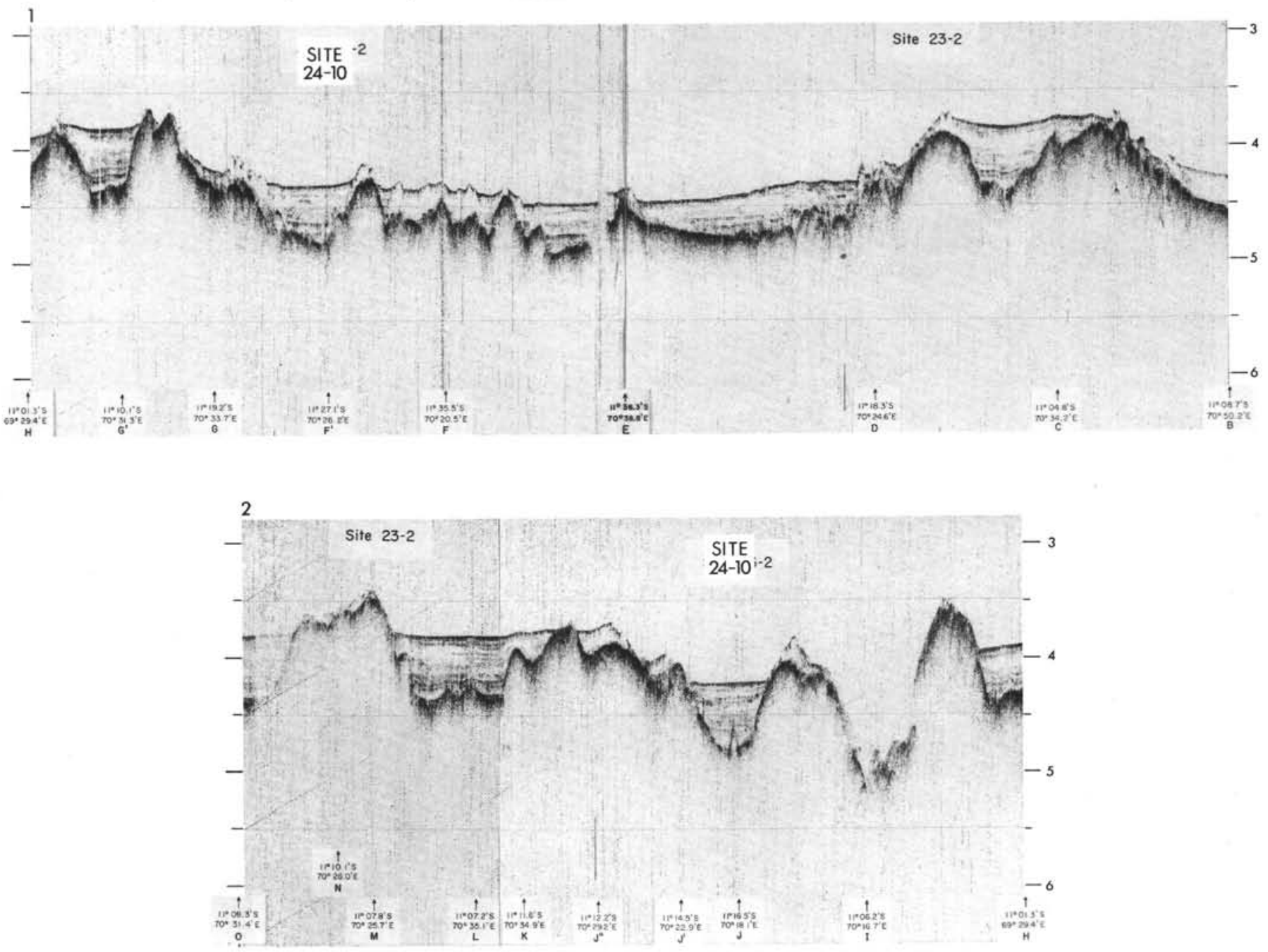

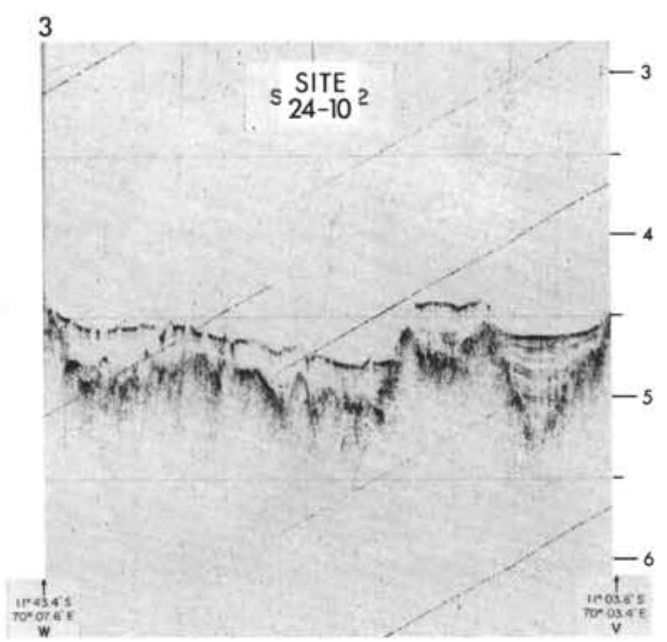

NOTE: See Figure 11 for locatic of reflection profiles.

Figure 13. Selected airgun profiles, Site Survey 24-10.

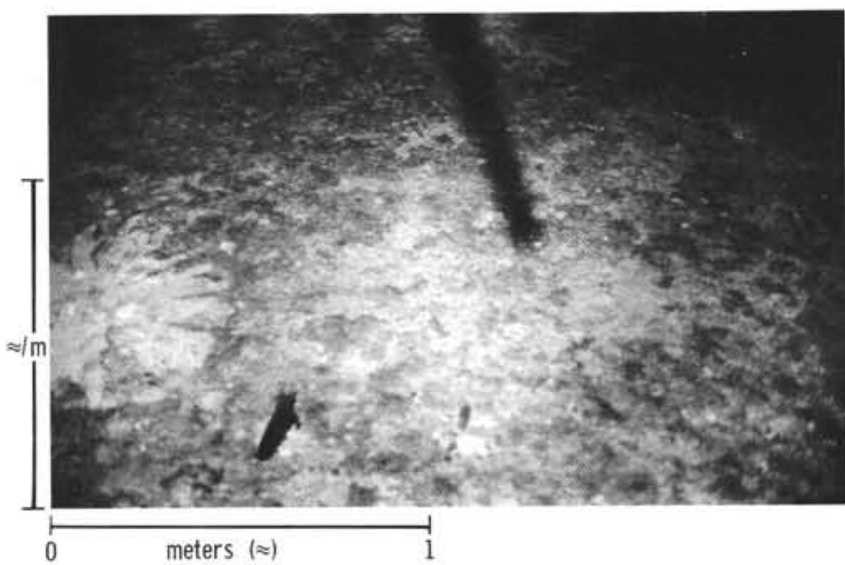

NOTE: The "shadow" is a dangling weighted rod; its purpose is to

DEPTH: $2819 \mathrm{~m}$ indicate the vertical.

$1110.1^{\prime} \mathrm{S}$

$7029.8^{\prime} \mathrm{E}$

Figure 14. Typical discolored bottom, and holothurian, at ANTP 121C. 